\title{
DESIGN AND INVESTIGATION OF MACHINE TOOL BED BASED ON POLYMER CONCRETE MIXTURE
}

\author{
Poklemba, R.; Duplakova, D.\#; Zajac, J.; Duplak, J.; Simkulet, V. \& Goldyniak, D. \\ Technical University of Kosice, Faculty of Manufacturing Technologies with a seat in Presov, \\ Bayerova 1, 08001 Presov, Slovakia \\ E-Mail: darina.duplakova@tuke.sk ( ${ }^{\#}$ Corresponding author)
}

\begin{abstract}
Presented paper is focused on the modelling and description of the proposal of composite frame construction of the new CNC machine, which is designed for progressive machining of products made of powder materials produced by the additive Direct metal laser sintering technology. In the introduction of the article, the uniqueness of the created bed design of the machine tool based on the mixture of polymer concrete is emphasized through general knowledge. Subsequently, the paper determines the properties of the polymer concrete mixture, which forms the basic material of the machine tool bed, describes the design of the CAD solution and the complex strength analysis at the determined load of $950 \mathrm{~N}$ with the subsequent interpretation of the results. Within the stress analysis, the Von Mises combined voltage is in the range of $0.2-0.4 \mathrm{MPa}$, thus meeting the required values of the formed material. In order to ensure the complexity of the evaluation of the proposed design solution, the results achieved by modal analysis are also presented in the paper. The conclusion of the article provides an overall summary of the achieved results and describes the further direction of research.

(Received in April 2020, accepted in May 2020. This paper was with the authors 2 weeks for 1 revision.)
\end{abstract}

Key Words: Polymer Concrete, Bed Machine, Stress Analysis, Modal Analysis

\section{INTRODUCTION}

The first experiments aimed at creating new material, the so-called synthetic concrete, took place around 1950. At that time, the first patents containing the particular ingredients used and their share in the total volume of the mixture were registered. The term synthetic concrete does not describe the essence of this material. Each type of concrete, as well as other manmade materials subject to certain adjustments or processing phases, is artificial (synthetic). Unlike cement concrete, the binder of the polymer concrete consists exclusively of synthetic macromolecular mass (synthetic resin). Therefore, the process of solidification of these two materials is completely different. In the first case, the cement binder is hydrated with water, and in the case of polymers, polycondensation of the synthetic resin, supplied to the mixture in the monomer state, takes place [1,2].

Research, analysis and assessment of machine tool beds made of polymer concrete composite materials are carried out by several experts worldwide. Yin et al. described the effect of glass fibres located in mineral composite on mechanical properties - the flexural strength and the compressive strength. The mechanical properties were influenced by the length and mass fraction and oxidation parameters. There were determined the values presented in percentage [3]. During the last year, the effect of resin fractal dimension in polymer concrete on mechanical properties was described. According to obtained results, it was stated that the overall performance of polymer concrete was correlated with resin content [4]. The static and dynamic characteristics of nettle polyester composite lathe bed were studied by Mahendrakumar et al. In this experiment, the FEA of cast iron lathe bed and nettle polyester lathe bed was carried out. The modification of form design was identified. The final stage of the experiment consists of NP composite lathe bed construction and verification of its dynamic characteristics in real conditions. According to results, the NP composite is suitable 
as a construction material in lathe bed [5]. The dynamic characteristics of the composite bed were investigated by authors Rangasamy et al. Authors carried out the experimental and numerical modal analysis for a composite and cast iron bed. The results show that the damping ratio and natural frequency of composite bed are 3 times better than the cast iron bed [6]. The Finite element analysis was used for characteristic determination of epoxy resin concrete $\mathrm{CNC}$ lathe bed and cast iron $\mathrm{CNC}$ lathe bed. According to results, the performances of ER concrete CNC lathe bed exceeding to cast iron material [7]. As you can see, some of them in their studies deals with assessing of mechanical properties, others are devoted to assessing the overall ratio of individual components within the performance characteristics of machine tools made of these mixtures, or they are dealing with the determination of static and dynamic characteristics and so on [8-23]. The basic idea arose from the real requirement to create and describe new material using simulation as a supporting tool that will form the basis for a machine tool bed. Based on a worldwide survey of the research carried out, the results of similar research that would track the development and production of new material as part of a CNC machine designed for machining parts manufactured using Direct Metal Laser Sintering (DMLS) technology are not published. The basic problem is thus to define a new material that will be implemented in special CNC machines intended for machining special parts made by DMLS technology as a substitute for conventionally used cast iron. The submitted paper pays attention to the description of the model proposal of a new CNC milling machine tool bed based on polymer concrete, which is designed for progressive machining of products made of powder materials produced by the additive DMLS technology with the subsequent interpretation of the evaluation of realized analyses on the proposed model.

\section{MATERIAL AND METHOD}

Creation of a proposed solution of a special CNC frame designed for progressive machining of products made of powder materials produced by additive DMLS technology with elementary building component formed by newly developed composite material with carbon fibre admixture preceded the research and development of this special polymer concrete mix, Fig. 1.

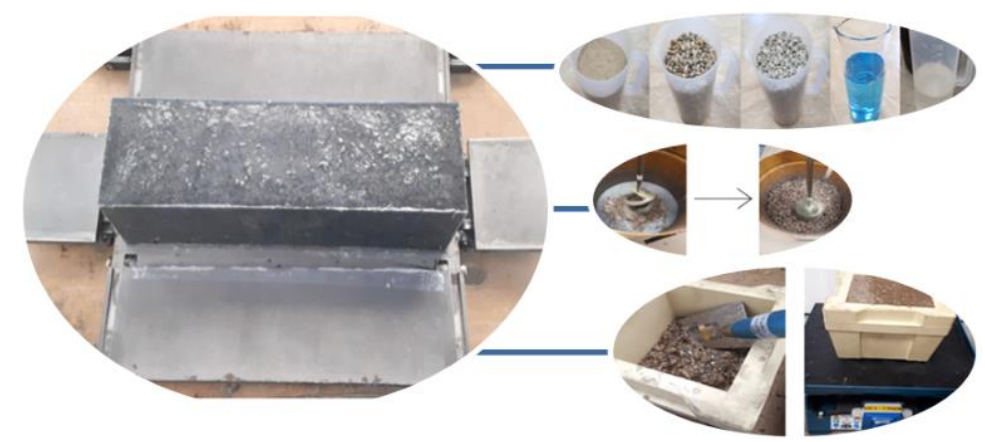

Figure 1: Research and development of special polymer concrete mixture [24, 25].

The mixture was formed at a ratio of $75 \%$ filler consisting of $3 \mathrm{~mm}$ long carbon fibres in the form of scattered reinforcement and $25 \%$ binder containing epoxy resin and hardener [24]. The prepared mixture has special properties, see Table I.

The polymer concrete mix in the form of test samples were subjected to several series of tests - compressive strength tests, bending tensile stress tests, evaluation of hardness and microstructure, Fig. 2. After realization of checking the shape and dimensions specified in the relevant standards, compressive strength tests were realized in accordance with norm STN EN 12390-3 The test sample was placed centrally on the lower pressure plate so that the centre deviation was not more than $\pm 1 \%$ of the cube edge length and rotated so that the compressive 
strength acts perpendicularly to the direction in which the polymer concrete was put into the mould, i.e. the upper surface of the cast to the side. Thereafter, the constant loading speed of the test sample was set with the subsequent testing another of the tests of mechanical properties was the measurement of bending tensile strength according to norm STN EN 12390-5. The spacing of the upper load rollers and the lower support rollers were set on the test press. A detailed description of the testing process with the achieved results obtained is given in the publications [24-26].

Table I: Properties of polymer concrete composite [24, 26].

\begin{tabular}{|l|c|}
\hline \multicolumn{2}{|c|}{ Filler - andesite gravel } \\
\hline Size of fraction $[\mathrm{mm}]$ & $4-8$ \\
\hline Water absorption $[\%]$ & $0.5-2.5$ \\
\hline Specific gravity $\left[\mathrm{kg} / \mathrm{m}^{3}\right]$ & 2400 \\
\hline \multicolumn{2}{|c|}{ Filler - silica sands } \\
\hline Size of fraction [mm] & $0.06-1.2$ \\
\hline Water absorption [\%] & $0.1-0.3$ \\
\hline Specific gravity $\left[\mathrm{kg} / \mathrm{m}^{3}\right]$ & $2500-2700$ \\
\hline \multicolumn{2}{|c|}{ Matrix - epoxy resin/hardener } \\
\hline Peel strength $[\mathrm{N} / \mathrm{cm}]$ & 14 \\
\hline Shear strength $[\mathrm{MPa}]$ & 25 \\
\hline Max. temperature $\left[{ }^{\circ} \mathrm{C}\right]$ & 80 \\
\hline Tensiblity $[\%]$ & 3 \\
\hline
\end{tabular}
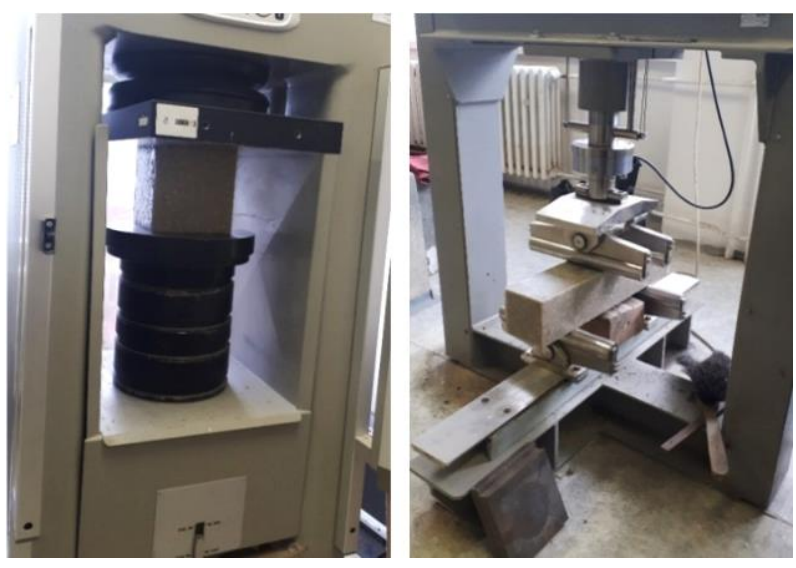

Figure 2: Realization of tests [27].

When evaluating the microstructure, the samples were steamed of carbon for observation to maintain electron beam conductivity. The composite material samples were observed at $80 \times, 400 \times$ and $2000 \times$ magnifications, Fig. 3. During the observation, a ductile failure of the fracture surface was noted with visible aggregate places in various forms (spherical and spongy shape). At a magnification of $400 \times$, a good peel in the resin can also be seen what indicate the presence of air cavities in the polymerization process or arose by plucked out of aggregate particles of spherical shape. The reinforcing carbon fibres used are sufficiently coated with resin.

During the observation was also evaluated the material distribution by mapping the chemical composition of carbon, oxygen, and aluminium, Fig. 4. At the same observed magnification, the distribution of filler and binder is visible. The binder of the resin form is represented by a red colour containing the carbon component. The aggregate as a filler contains oxygen and aluminium. Oxygen has a lower proportion, suggesting an associated silicon and aluminium component in the form of $\mathrm{SiO}_{2}$ and $\mathrm{Al}_{2} \mathrm{O}_{3}$. 

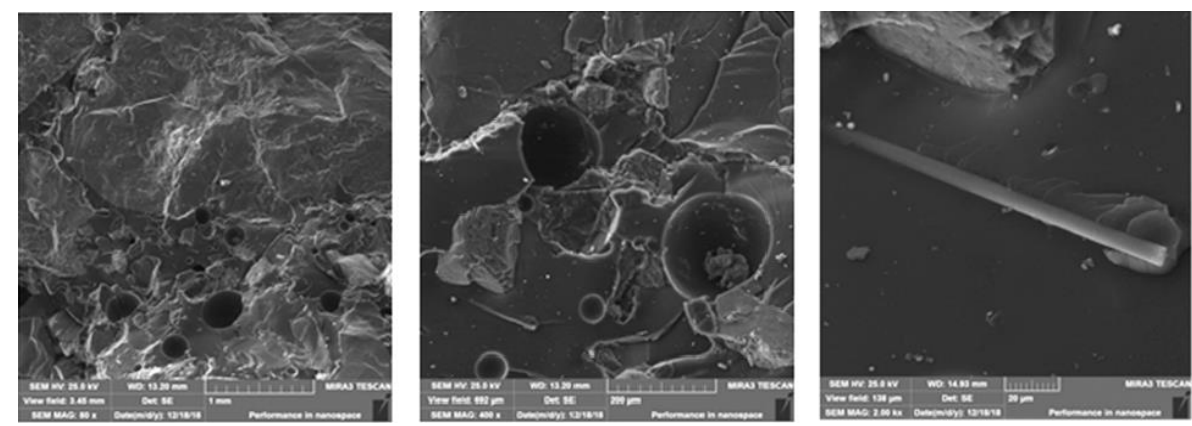

Figure 3: Fracture surface morphology of polymer concrete mixture: magnification $80 \times$ (left), magnification $400 \times($ centre $)$, magnification $2000 \times($ right $)$.
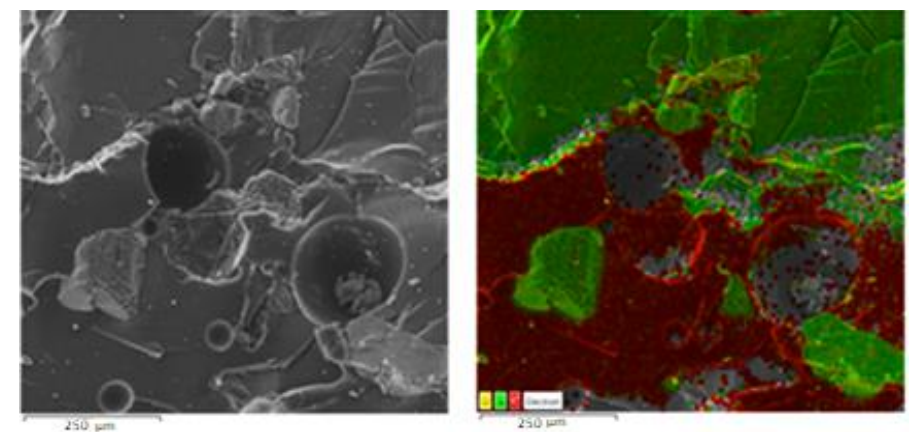

Figure 4: Chemical mapping of polymer concrete mixture.

Properties of new composite material based on polymer concrete mixture obtained by long-term research were implemented into computer design solution where stress analyses were realized, through the stress-strain states and reduced stresses were assessed according to the HMH condition (Von Mises stress) by reason of the assessment of the limit state of elasticity. The criterion of the dangerous state is the maximum specific deformation energy necessary for the shape change. The HMH strength hypothesis assumes that a dangerous state occurs when the specific strain energy to change the shape of given stress exceeds the value of the specific strain energy to change the shape of straight line stress at which a failure occurs. The condition of the Von Mises stress is given by Eq. (1) [28]:

where:

$$
\sigma_{\text {red }} \leq \sigma_{D}
$$

$\sigma_{\text {red }}$ - reduced stress $[\mathrm{MPa}]$,

$\sigma_{D}-$ maximum permissible stress determined by values of yield point $\operatorname{Re}[\mathrm{MPa}]$.

From the previous equation, it is necessary to determine the reduced stress, which has the following form [28]:

$$
\sigma_{\text {red }}=\sqrt{\sigma_{1}^{2}+\sigma_{2}^{2}+\sigma_{3}^{2}-\left(\sigma_{1} \sigma_{2}+\sigma_{2} \sigma_{3}+\sigma_{3} \sigma_{1}\right)}
$$

where:

$\sigma_{1}, \sigma_{2}, \sigma_{3}-$ main stresses in the individual direction [MPa]

or

where:

$$
\sigma_{\text {red }}=\sqrt{\sigma_{x}^{2}+\sigma_{y}^{2}+\sigma_{z}^{2}-\left(\sigma_{x} \sigma_{y}+\sigma_{y} \sigma_{z}+\sigma_{z} \sigma_{x}\right)+3\left(\tau_{x}^{2}+\tau_{y}^{2}+\tau_{z}^{2}\right)}
$$

$\sigma_{x}, \sigma_{y}, \sigma_{z}$-normal stress components in directions $\mathrm{x}, \mathrm{y}, \mathrm{z}$ [MPa],

$\tau_{x}, \tau_{y}, \tau_{z}$ - shear stress components [MPa].

In addition to static stress analysis, it is necessary to obtain a set of data values through the modal analysis realization, which has an irreplaceable role in the diagnosis of machine vibration. Thought the modal analysis is set oscillation shapes, natural frequencies and modal 
damping of mechanical systems. The method of modal analysis can solve many technical problems encountered in the design, manufacture or operation of mechanical assemblies or parts thereof. Modal analysis is most commonly used for the following reasons [29]:

- Comparison of experimentally obtained data on the prototype with the corresponding data obtained by the finite element method and optimization of the analytical model to correspond to the real one, which would be used for further calculations and simulations. This optimized model is free of errors that are introduced into the calculation when all boundary conditions are insufficiently included.

- With the help of the resulting natural frequencies, it is possible to identify dangerous operating states that the device must not reach. If the natural frequencies coincided with the frequencies of the excitation forces, the system would resonate, which in turn would reduce its lifespan multiple times, increase noise and, last but not least, may cause damage.

- Thanks to the resulting excited oscillation shapes of the investigated system it is possible to determine the locations of its maximum deflections. Based on places of maximum displacements defined, structural modifications can be made (modification of geometry, the addition of additional elements, change of material characteristics, etc.) to eliminate dangerous vibrations.

- The resulting modal parameters are also used to identify disorders as well as their locations. Certain disturbances show specific displays in the spectrum of the sensed signal, such as e.g. imbalance, misalignment etc.

Using the above-mentioned material properties and basic mathematical approaches, a new design solution for a special $\mathrm{CNC}$ machine frame was design for machining parts manufactured using by Direct metal laser sintering technology was subsequently developed.

\section{DESIGN OF MACHINE TOOL BED}

Machine tool bed made of polymer concrete requires different design procedures than regular cast iron applications. The stand should be of a simple solid structure, ideally cube-shaped. The thickness of the walls of the polymer concrete frame is approximately three times larger than that of the cast iron castings (about $60-80 \mathrm{~mm}$ ). In this case, it is necessary to observe the minimum wall thickness rule - if the coarse filler fraction is $16 \mathrm{~mm}$, then the critical minimum wall thickness is $80 \mathrm{~mm}$. Thin walls at the top of the casting may be cast additionally from the mixture with finer fractions than the polymer concrete of the underlying solid structure.

With polymer concrete, different casting thicknesses are accepted unlike in case of the cast iron applications, since the internal strain of the polymer concrete is negligible. A great advantage of polymer concrete castings is the possibility of using an almost unlimited selection of raw material because the casting takes place in cold conditions when the max. temperature of the exothermic reaction is $45-50{ }^{\circ} \mathrm{C}$. It is possible to install wiring, hydraulic or pneumatic distribution ducts inside the mould in addition to clamping raw material and shape bridges. Due to small shrinking, sensitive temperature sensors or other electronics may be integrated smoothly. In the case of steel moulds, the accuracy of the raw material placement is $\pm 0.1 \mathrm{~mm}$. For economic and implementation reasons, the number of the types of clamping raw material should be as small as possible.

The most stressed are the support brackets with hanging bolts for fixing the crane rope or chain. In order to ensure a good connection of the brackets with the casting, the cylindrical part with the internal thread ends with a corrugated circular profile. Special types of raw material include metal or pipe systems (pneumatic and hydraulic distribution systems, coolant lines, and lubricants), electrical installations, precision metal plate surfaces and strips for additional milling, stainless steel guard sheets against mechanical wear of the castings, bathtubs and stainless steel containers for cutting and cooling liquids. The lower part should 
be skewed so that air bubbles do not remain there during the casting procedure. Damage to the lower part of the frame or the stand during transport can be avoided by grouting two Ushaped sheet profiles with a width of a forklift truck. All edges of the casting should be rounded to eliminate stress concentration. The casting may include holes for installation of controls, aggregates, and the like. The electrical grounding of the machine with an electrically non-conductive polymer concrete stand is done by grouting the wires, thus connecting the metal raw material with the base plate.

A polymer concrete casting must be designed with minimum requirements for additional mechanical machining, comparable to the methods of natural stone processing. The ideal technology for joining several components made of polymer concrete is bonding technology.

A very important part of each stand or frame is the guiding surfaces (sliding, hydrostatic, aerostatic), spindle bearing surfaces and other precise mounting surfaces for attaching guide rails or linear drives. The achieved geometric accuracy is dependent on the choice of manufacturing technology. Retrofit technology for encased metal sheets and precision grinding technology for underlying wiring surfaces are costly and hence seldom used. A more preferred alternative is casting precision surfaces directly onto a polymer concrete substrate with a shape accuracy of several thousand millimetres. In this way, the cost of mechanical machining is eliminated, too. The metal guide strips are fastened to the casting by means of screws. It is not recommended to encase and bond the guide strips due to thermal stress caused by different thermal expansion. Due to poor heat dissipation, uneven overheating and shape deformations of the stand may occur. Important measures include the use of thermally symmetrical structures, conductivity improved with metal fillers or special raw materials, and the incorporation of a heating and cooling circuit.

Based on the above-mentioned rules, a composite frame design for a special CNC machine used for machining components produced by Direct metal laser sintering technology was created, Fig. 5.
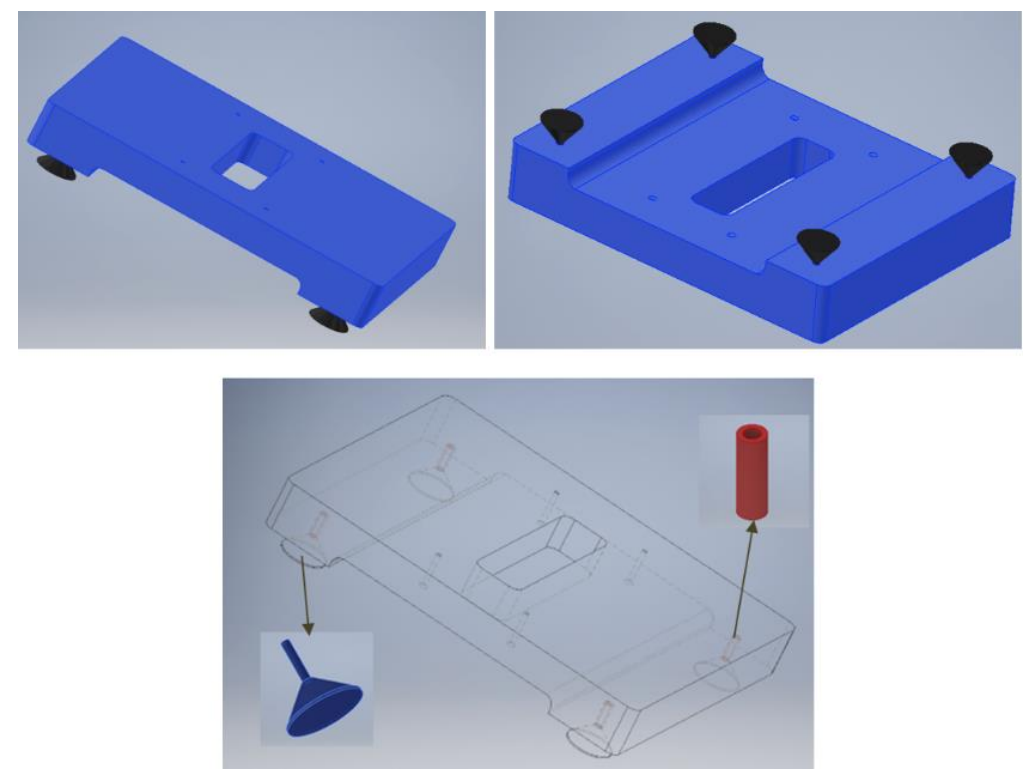

Figure 5: 3D model of construction design of machine tool bed.

The basic part of the frame consists of a composite plate, which provides damping of vibrations and shocks entering the machining process. Height-adjustable feet are mounted in the composite plate to set the machine in a horizontal position and centre it. The relief hole located in the centre of the composite plate and the relief recess located on the underside of the composite plate serve to reduce the total operating weight of the proposed device so that it is mobile and easy to carry as it is a special CNC machine of smaller dimensions. The fixing 
and anchoring of the basic functional parts are provided by means of anchoring sleeves which are located around the relief hole.

This composite frame provides the $\mathrm{CNC}$ with the necessary rigidity, stability and damping effects, i.e. the basic factors necessary for machining hard-to-machine technical materials, among which powder tool steel is classified.

After the creation of the basic model of the composite frame of the CNC machine, the basic settings were defined to enable the subsequent realization of the strength analysis. The used materials and their physical properties were determined with the subsequent setting of boundary conditions for the subsequent assessment of stress-strain states and reduced stress. When selecting individual materials within the definition of input parameters of analysis it was necessary to define a new material whose properties are given in Table I. In addition to the definition of a new composite material used as the basic building element of the device frame, the material of height-adjustable feet and anchoring bushes was defined - unalloyed steel, where $R e=250 \mathrm{MPa}$ and $R m=300 \mathrm{MPa}$. The created CNC model was loaded with partial forces of $250 \mathrm{~N}$, in the places of fixtures of the main skeleton of the device, Fig. 6.

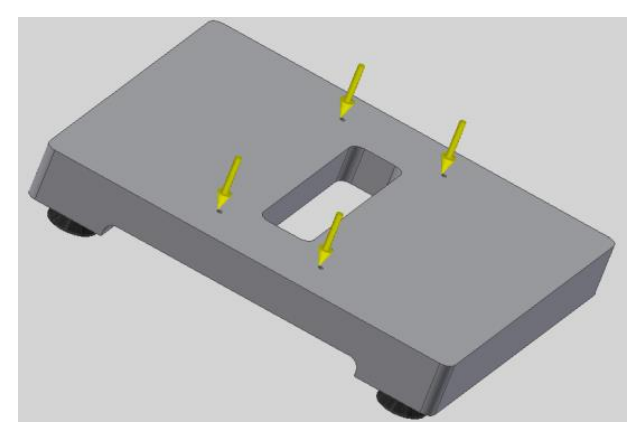

Figure 6: Distribution of the loading forces.

To consider assess the dynamics of the proposed solution, a modal analysis was also realized, in which the dynamic behaviour of the created design solution was assessed. Described model and individual analyses were created in Autodesk Inventor with using Analysis Module. The results of individual analyses that have been recorded are described in the following section of the article.

\section{RESULTS AND DISCUSSION}

As part of the realization of static analysis, the Von Mises combined stress was considered as the main parameter. According to the analysis made, it is obvious that the highest stress is accumulated in the places used for attaching the device. In these places, the stress reaches a value in the range of $0.2-0.4 \mathrm{MPa}$, and it can be stated that this range suits with the maximum allowable stress, Fig. 7.
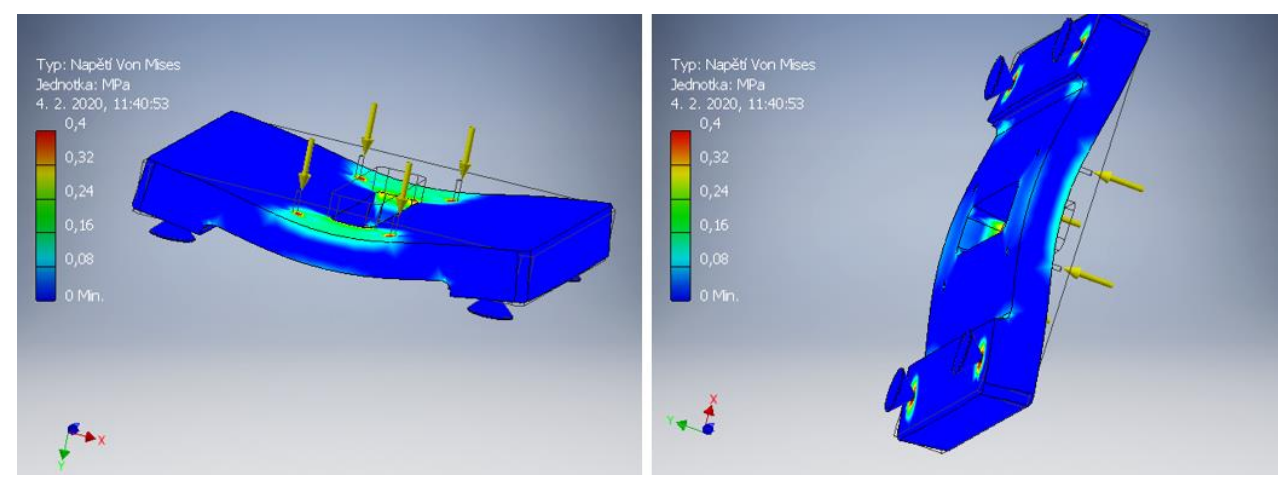

Figure 7: Stress analysis - combined stress Von Mises. 
When assessing the first and third main stress, the values ranged from -9.142 MPa up to $3.902 \mathrm{MPa}$ and thus not only the tensile but also the compressive stress acts on the depicted places, Fig. 8.

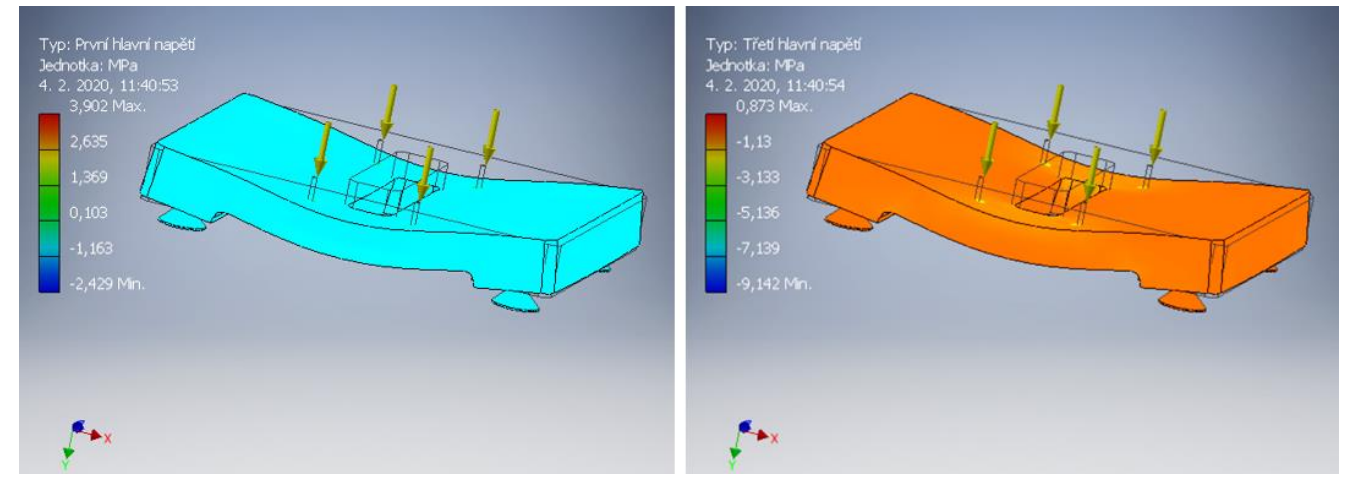

Figure 8: Stress analysis - the main stresses.

Within the deformation assessment, the contact pressure on the assessed area of $29.98 \mathrm{MPa}$ creates a maximum total deformation of $0.011 \mathrm{~mm}$. In regard to the data obtained, it can be stated that the deformation created in the displacement design is minimal and has a negligible effect on the overall strength of the proposed frame, Fig. 9.
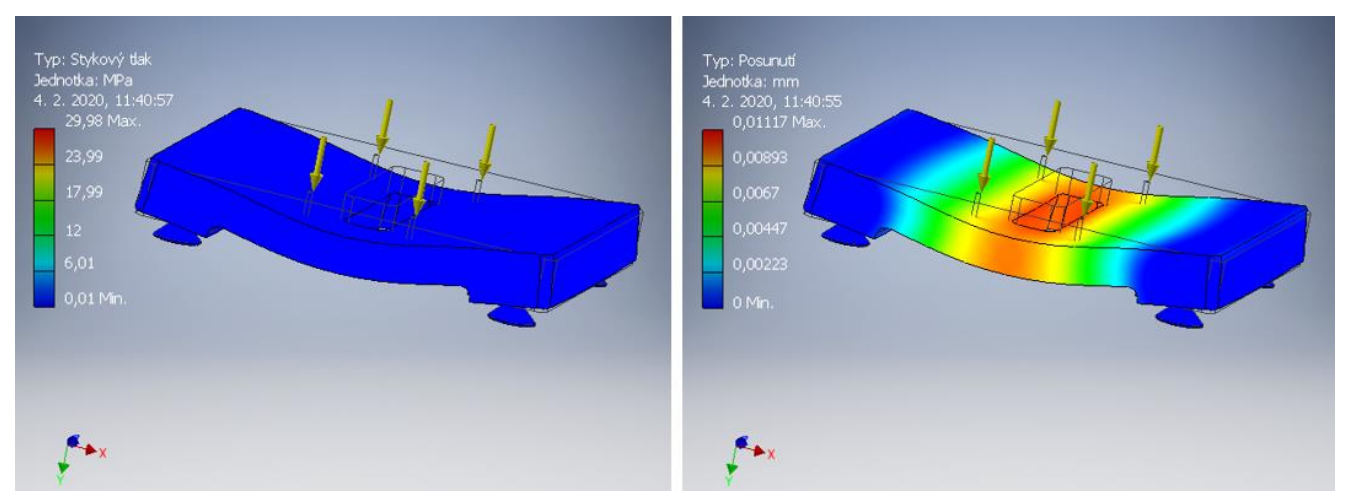

Figure 9: Stress analysis - touch pressure (left) and displacement (right).

Using the software support, numerical modal analysis was also realized, through which the custom shapes and their respective own frequencies were obtained, Fig. 10. Through this analysis, the behaviour of modal parameters was identified, Table II.

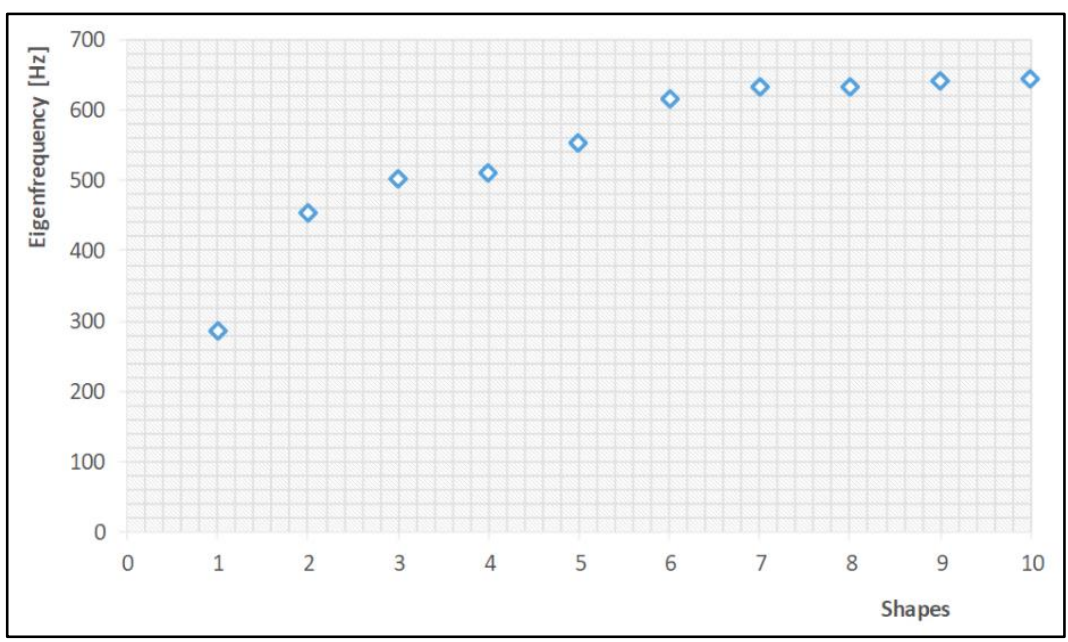

Figure 10: Graphical interpretation of natural frequencies in individual shapes. 
Table II: Results of modal analysis.

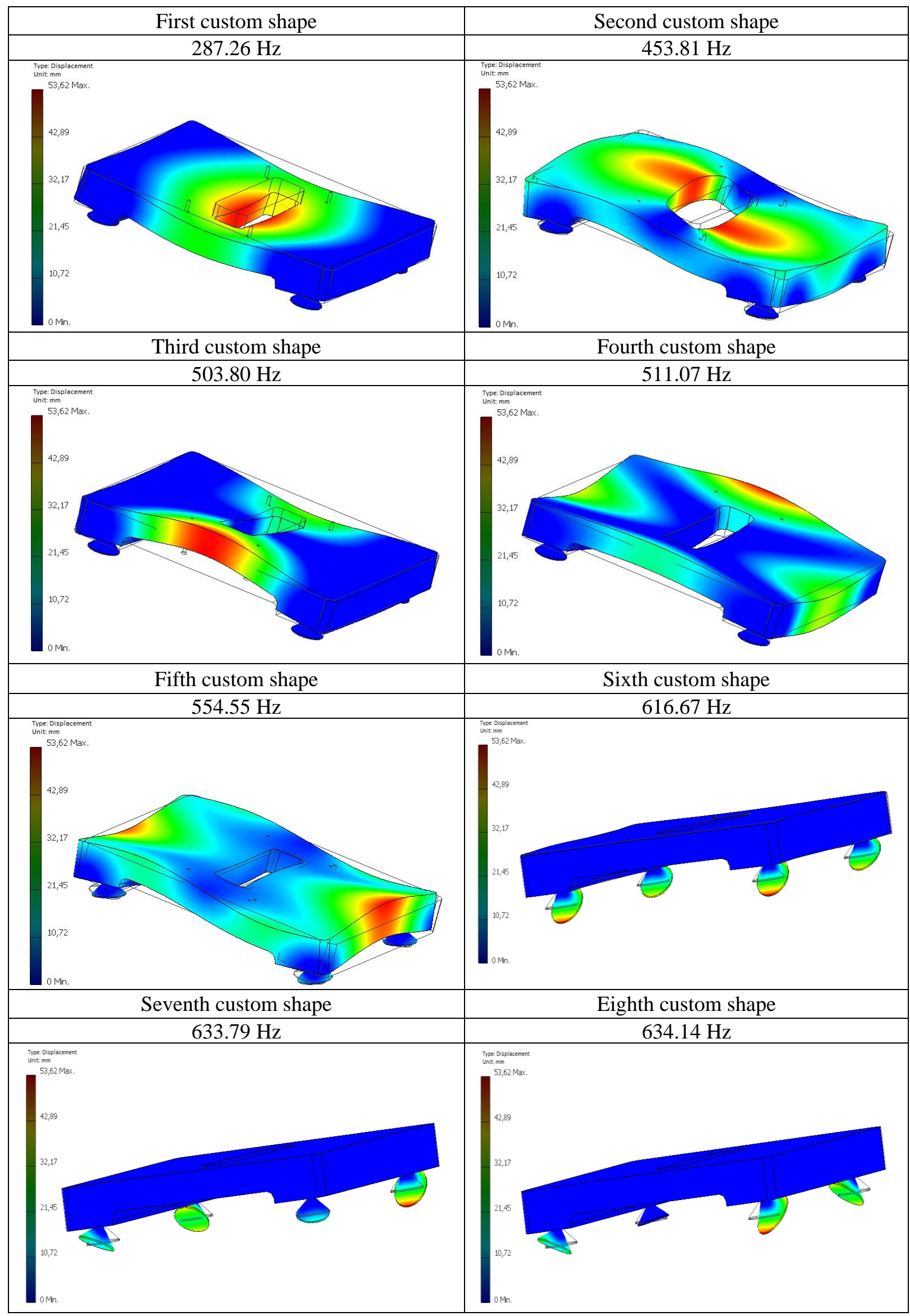




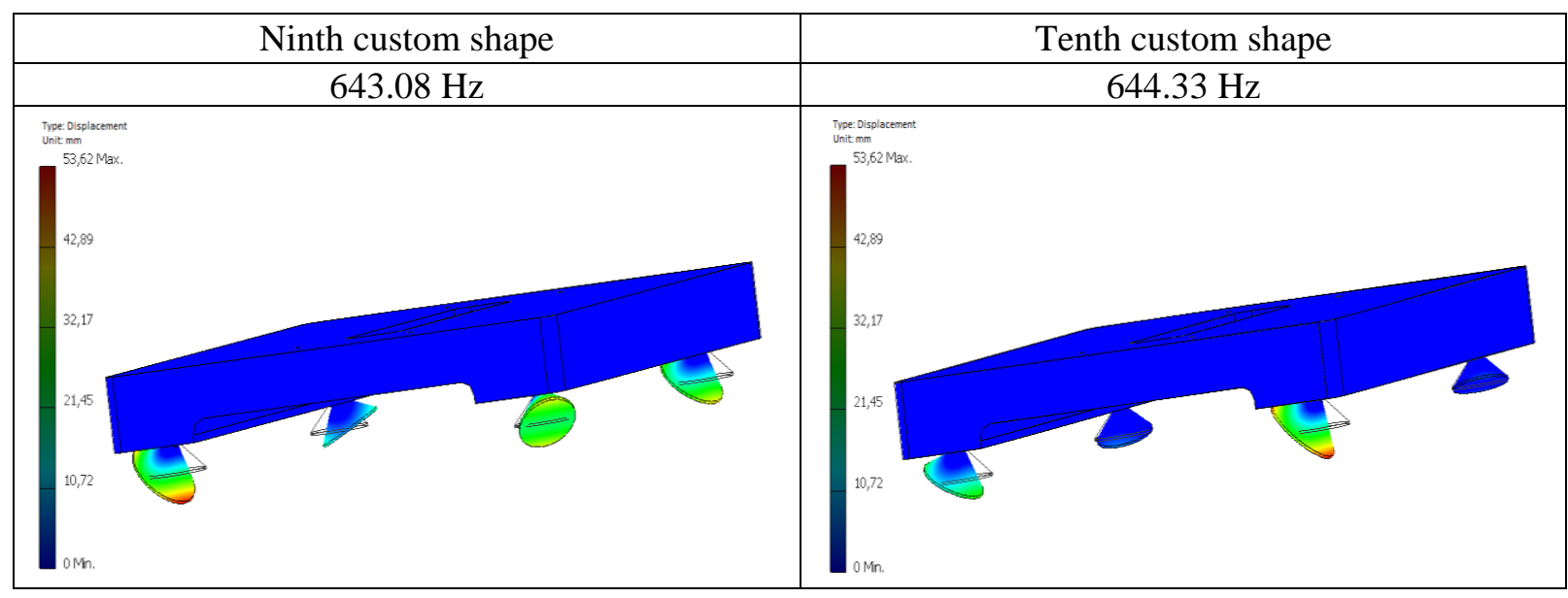

\section{CONCLUSION}

This paper provides complete information about the new composite material and its behaviour as a part of a milling machine for DMLS parts machining. This paper is a presentation of the development and manufacturing of unique material as a part of a special milling machine. On the basis of complex strength analysis, it can be stated that the proposed design of a composite material frame for special CNC device complies with all assessed parameters, which enables real production and the product to undergo a series of practical stress tests, which are subject to further research. In the frame of modal analysis will also verify the accuracy of the results through further research obtained by numerical calculations with results of experimental modal analysis, realized after the production of a special composite frame for CNC machines designed for machining parts manufactured by direct metal laser sintering technology. These results may form the basis for producing materials designated for similar problems as we described. The original contribution of the paper is considered to be the presentation of the creation of new material and the description of its properties and behaviour as part of a CNC machine specifically designed to machine components created by DMLS technology using computer-aided technologies.

\section{ACKNOWLEDGEMENT}

This work was supported by the Slovak Research and Development Agency under the contract No. APVV-15-0700. Article is the result of the Project implementation: Automation and robotization for $21^{\text {st }}$ century manufacturing processes, ITMS: 313011T566, supported by the Operational Programme Research and Innovation funded by the ERDF.

\section{REFERENCES}

[1] Biernacki, J. J.; Bullard, J. W.; Sant, G.; Brown, K.; Glasser, F. P.; Jones, S.; Ley, T.; Livingston, R.; Nicoleau, L.; Olek, J.; Sanchez, F.; Shahsavari, R.; Stutzman, P. E.; Sobolev, K.; Prater, T. (2017). Cements in the $21^{\text {st }}$ century: challenges, perspectives, and opportunities, Journal of the American Ceramic Society, Vol. 100, No. 7, 2746-2773, doi:10.1111/jace.14948

[2] Duplakova, D.; Duplak, J.; Soltes, P. (2019). Current Scientific Knowledge About New Composite Materials on the Basis of Polymer Concrete, $1^{\text {st }}$ edition, Ram-Verlag, Lüdenscheid

[3] Yin, J.; Zhang, J.; Wang, W.; Ren, X. (2017). Effect of glass fiber surface treatment on the mechanical strength of glass fiber reinforced resin mineral composite for machine tool bed, Polymer Composites, Vol. 38, No. 8, 1559-1570, doi:10.1002/pc.23723

[4] Yin, J.; Zhang, J.; Wang, W. (2019). Effective resin content and its effect on the overall performance of polymer concrete for precision machine tools, Construction and Building Materials, Vol. 222, 203-212, doi:10.1016/j.conbuildmat.2019.06.144 
[5] Mahendrakumar, N.; Thyla, P. R.; Mohanram, P. V.; Raja Kumaran, C.; Jayachandresh, J. (2019). Study on static and dynamic characteristics of nettle-polyester composite micro lathe bed, Proceedings of the Institution of Mechanical Engineers, Part L: Journal of Materials: Design and Applications, Vol. 233, No. 2, 141-155, doi:10.1177/1464420716663568

[6] Rangasamy, S.; Loganathan, K.; Natesan, A. (2017). Experimental investigation and numerical analysis of the dynamic characteristics of a laminated hybrid composite bed, Polymer Composites, Vol. 38, No. 1, 20-26, doi:10.1002/pc.23555

[7] Qiao, X. T.; Li, Y. S.; Zhao, H. Y.; Wu, L.; Zhao, Z. X. (2011). Study on performances and its structural designing of the high-speed $\mathrm{CNC}$ lathe epoxy resin concrete bed, Advanced Materials Research, Vol. 189, 4370-4376, doi:10.4028/www.scientific.net/AMR.189-193.4370

[8] Murugan, S.; Thyla, P. R. (2018). Mechanical and dynamic properties of alternate materials for machine tool structures: a review, Journal of Reinforced Plastics and Composites, Vol. 37, No. 24, 1456-1467, doi:10.1177/0731684418799946

[9] Lu, D.; Fan, Y.; Wu, W. (2017). An exploration on dynamic characteristics of the machine tool bed made of resin mineral composites, Machinery, Vol. 2017, No. 1, 4 pages

[10] Yu, Y.-H.; Liang, Y.; Shen, J.-X.; Xu, P.; Zhang, W.-L. (2017). Structure design and performance simulation of a machine tool components made of BFPC, Journal of Machine Design, Vol. 34, No. 1, 71-75

[11] Dunaj, P.; Berczyński, S.; Chodźko, M. (2019). Modelling of a steel-polymer concrete machine tool frame component, Majewski, M.; Kacalak, W. (Eds.), Innovations Induced by Research in Technical Systems, IIRTS 2019, Lecture Notes in Mechanical Engineering, Springer, Cham, 1324, doi:10.1007/978-3-030-37566-9_2

[12] Chen, Y.; Wei, J.; Wang, Y.-X. (2016). Analysis into static and dynamic performances of a resin machine tool bed, Journal of Nanjing Institute of Technology (Natural Science Edition), Vol. 2016, No. 2, 49-52

[13] Poklemba, R.; Zajac, J.; Duplakova, D.; Petruška, O. (2020). Design of bed machine for machine tool based on polymer concrete mixtures, TEM Journal, Vol. 9, No. 1, 25-29, doi:10.18421/TEM91-04

[14] Zhou, Y.; Cai, C.; Zhou, S. (2016). Static/dynamic analysis and optimization of z-axis stand of PCB CNC drilling machine, MATEC Web of Conferences, Vol. 40, Paper 02012, 5 pages, doi: $10.1051 /$ matecconf $/ 20164002012$

[15] Knapcikova, L.; Husar, J.; Herzog, M.; Pesek, L. (2012). Testing of new composite materials based on fabric from used tires, Chemicke listy, Vol. 106, S450-S452

[16] Valíček, J.; Harničárová, M.; Kopal, I.; Palková, Z.; Kušnerová, M.; Panda, A.; Šepelák, V. (2017). Identification of upper and lower level yield strength in materials, Materials, Vol. 10, No. 9, Paper 982, 20 pages, doi:10.3390/ma10090982

[17] Drbul, M.; Czán, A.; Šajgalík, M.; Piešová, M.; Stępień, K. (2017). Influence of normal vectors on the accuracy of product's geometrical specification, Procedia Engineering, Vol. 192, 119-123, doi: $10.1016 /$ j.proeng.2017.06.021

[18] Hutyrová, Z.; Zajac, J.; Michalik, P.; Mital', D.; Duplák, J.; Gajdoš, S. (2015). Study of surface roughness of machined polymer composite material, International Journal of Polymer Science, Vol. 2015, Paper 303517, 6 pages, doi:10.1155/2015/303517

[19] Ni, Y.; Liu, X.; Zhang, B.; Zhang, Z.; Li, J. (2018). Geometric error measurement and identification for rotational axes of a five-axis CNC machine tool, Strojniski vestnik - Journal of Mechanical Engineering, Vol. 64, No. 5, 290-302, doi:10.5545/sv-jme.2017.4581

[20] Uchanin, V.; Minakov, S.; Nardoni, G.; Ostash, O.; Fomichov, S. (2018). Nondestructive determination of stresses in steel components by eddy current method, Strojniski vestnik Journal of Mechanical Engineering, Vol. 64, No. 11, 690-697, doi:10.5545/sv-jme.2018.5208

[21] Martini, A. (2018). Gravity compensation of a 6-UPS parallel kinematics machine tool through elastically balanced constant-force generators, FME Transactions, Vol. 46, No. 1, 10-16, doi:10.5937/fmet $1801010 \mathrm{M}$

[22] Straka, M.; Hurna, S.; Bozogan, M.; Spirkova, D. (2019). Using continuous simulation for identifying bottlenecks in specific operation, International Journal of Simulation Modelling, Vol. 18, No. 3, 408-419, doi:10.2507/IJSIMM18(3)477 
[23] Trofimov, A.; Mishurova, T.; Lanzoni, L.; Radi, E.; Bruno, G.; Sevostianov, I. (2018). Microstructural analysis and mechanical properties of concrete reinforced with polymer short fibers, International Journal of Engineering Science, Vol. 133, 210-218, doi:10.1016/ j.ijengsci.2018.09.009

[24] Petruška, O.; Zajac, J.; Molnár, V.; Fedorko, G.; Tkáč, J. (2019). The effect of the carbon fiber content on the flexural strength of polymer concrete testing samples and the comparison of polymer concrete and U-shaped steel profile damping, Materials, Vol. 12, No. 12, Paper 1917, 17 pages, doi: $10.3390 / \mathrm{ma12121917}$

[25] Petruška, O.; Zajac, J.; Duplák, J.; Blaško, L. (2019). Testing of hardness of polymer concrete mixtures using a Schmidt hammer (Skúšanie tvrdosti polymérbetónových odliatkov Schmidtovým kladivkom), Proceedings of the 2019 Automatization and Control in Theory and Praxis (1 $3^{\text {th }}$ Conference ARTEP 2019), 10 pages (in Slovak)

[26] Petruška, O.; Zajac, J.; Botko, F.; Mital, D.; Knapcikova, L. (2018). Polymer concrete compositepreparation of testing sample, SAR Journal, Vol. 1, No. 4, 135-139, doi:10.18421/SAR14-03

[27] Duplakova, D.; Radchenko, S.; Botko, F.; Petruska, O.; Goldyniak, D. (2019). Research of new composite material for manufacturing CNC machines designed to machining of powder materials produced by the additive technology DMLS-testing of new composite material (Výskum nového kompozitného materiálu na výrobu $\mathrm{CNC}$ strojov pre progresívne obrábanie výrobkov z práškových materiálov vyrábaných aditívnou technológiou DMLS-skúšanie nového kompozitného materiálu), Proceedings of the 2019 Automatization and Control in Theory and Praxis (13 ${ }^{\text {th }}$ Conference ARTEP 2019), 8 pages (in Slovak)

[28] Jurkovic, M.; Kalina, T. (2019). Assessment of strength characteristics of LNG tanks on the vessels (Posúdenie pevnostných charakteristík LNG nádrží na plavidlách), Perner's contacts, Vol. 19, No. 1, 74-80 (in Czech)

[29] Frankovsky, P.; Gula, M.; Micko, D.; Hudak, P.; Hrivnak, J. (2011). Use of modal analysis in the diagnosis of machinery vibrations (Využitie modálnej analýzy pri diagnostike vibrácí́ strojných zariadení), Transfer inovácií, Vol. 19, 178-184 (in Slovak) 